\title{
Economic Threshold Levels for Signal Grass Control in Sugarcane Cultivars ${ }^{1}$
}

\author{
Nível de Dano Econômico de Braquiária sobre Cultivares de Cana-de-Açúcar
}

TIRONI, S.P. ${ }^{2}$, GALON, L. ${ }^{3}$, SILVA, A.A. ${ }^{4}$, BARBOSA, M.H.P. ${ }^{2}$, SILVA, A.F. ${ }^{5}$, and FERREIRA, E.A. ${ }^{6}$

\begin{abstract}
Weed management in sugarcane fields must be performed rationally, taking into consideration the competitive ability of cultivars and weeds, to allow for reductions in control costs and herbicide use. In this study, an evaluation was made of the interference of populations of Brachiaria brizantha in sugarcane cultivars, with the objective of estimating the economic threshold level of $B$. brizantha in competition with the cultivars RB72454, RB867515 and SP801816. For this purpose, an experiment was conducted under field conditions, where the cultivars coexisted with different weed densities. Considering the average values of the variables used for calculations, an economic threshold level was achieved with a population of $0.33,0.46$ and 0.66 plants $\mathrm{m}^{-2}$ of $B$. brizantha for cultivars RB867515, RB72454 and SP801816, respectively.
\end{abstract}

Keywords: Brachiaria brizantha, RB72454, RB867515; SP801816, Saccharum spp.

\begin{abstract}
RESUMO - O manejo das plantas daninhas nos canaviais deve ser realizado de forma racional, levando em consideração a habilidade competitiva dos cultivares e das plantas daninhas, podendo ser reduzido o custo de controle e o uso de herbicidas. Neste trabalho foi avaliada a interferência de populações de Brachiaria brizantha em cultivares de cana-de-açúcar, tendo como objetivo estimar o nivel de dano econômico da espécie daninha em competição com os cultivares RB72454, RB867515 e SP801816. Para isso, foi conduzido um experimento em campo, onde os cultivares conviveram com diferentes densidades populacionais da espécie daninha. Considerando valores médios das variáveis utilizadas no cálculo, o nível de dano econômico foi atingido com a população de 0,33, 0,46 e 0,66 planta $\mathrm{m}^{-2}$ de B. brizantha para os cultivares RB867515, RB72454 e SP801816, respectivamente.
\end{abstract}

Palavras-chave: Brachiaria brizantha, RB72454, RB867515, SP801816, Saccharum spp.

\section{INTRODUCTION}

Weed interference is one of the negative factors that affect sugarcane yield. They compete with crops for environmental resources such as water, nutrients, space and light, among other elements, limiting crop yield between 76.6 and $83.6 \%$, depending on the cultivar, when a crop is not managed properly (Yirefu et al., 2012).
Sugarcane presents a low competitive ability, because of its slow initial development; this means that the plant requires a long period free of weed interference, which varies from three to 12 weeks after planting (Yirefu et al., 2012), depending on environmental conditions. Some weed species have greater competitive ability, such as those of Brachiaria spp., which are usually found in sugarcane fields (Barbosa et al., 2013). B. brizantha

Recebido para publicação em 3.4.2016 e aprovado em 18.4.2016.

2 Universidade Federal da Fronteira Sul, Chapecó-SC, Brasil, <siumar.tironi@gmail.com>; ${ }^{3}$ Universidade Federal da Fronteira Sul, Erechim-RS, Brasil; ${ }^{4}$ Universidade Federal de Viçosa, Viçosa-MG, Brasil; ${ }^{5}$ Embrapa Milho e Sorgo, Sete Lagoas-MG, Brasil; ${ }^{6}$ Universidade Federal dos Vales do Jequitinhonha e Mucuri, Diamantina-MG, Brasil. 
promotes yield loss of $45.67 \%$ in sugarcane when not controlled (Tironi et al., 2012).

The chemical method is the most frequently used for weed control in sugarcane fields because of its practicality, high efficiency, low cost and rapidity, and also the extensive areas of cultivation (Odero et al., 2015). Considering the long period that a crop should remain free of weed interference, commonly used herbicides have a long residual effect on the soil to control weed emergence in the area.

Many of these herbicides should be applied to the soil before weed emergence. In this case, it is difficult to predict whether weed species that may cause damage to the crop will be found in a given area. This complicates justifying the cost of implementing a particular herbicide. Also, considering that infestation of one or a few species can be controlled by specific herbicides, this does not justify the application of formulated herbicides or mixtures that present a broad spectrum of control, which is usually performed on sugarcane crops in Brazil.

The presence of these herbicides that persist in the soil for long periods can result in environmental imbalances, such as damage to microorganisms present in this environment (Faria et al., 2014) and leaching of these products, which can affect watercourses (Queiroz et al., 2009). In this case, there is high environmental impact on aquatic organisms or on those who consume the contaminated water. In addition to environmental impacts, the intensive use of herbicides may represent a major part of the costs of sugarcane production, thus reducing farmers' profit margin.

One way to reduce the use of herbicides, thus diminishing production costs and environmental impacts, is to use them only when they are needed. This is the concept of an economic threshold level (ETL), a tool that helps farmers make decisions about weed control (Vidal et al., 2010; Westendorff et al., 2014).

Economic threshold level usually involves the use of regression equations or damage functions, which relate crop yield loss to an indicator that quantifies weed infestation, e.g., the population of plants, dry matter weight, or some environmental factors (Warner, 2007; Ali et al., 2014). The relative leaf cover of weeds at an early growth stage, estimated by images, can be used to predict yield loss when the crop is mature (Ali et al., 2014). ETL also differs according to the potential yield of the crop, the price of the product, efficiency and the cost of control (Lindquist and Kropff, 1996).

Several factors influence the competition between weeds and crops, and some of them may be associated with management practices such as the use of cultivars with greater competitive ability, as well as the density and arrangement of planting and fertilization, among other factors. These practices may favor the development of the crop to the detriment of weed species, thus increasing the population of weed species required to achieve ETL (Galon and Agostinetto, 2009; Westendorff et al., 2014).

In this sense, research needs to be conducted on the ETL of weed species in sugarcane cultivars, because ecophysiological characteristics may influence this feature, thus changing ETL and, consequently, decisions about weed control. Sprawling sugarcane cultivars appear to be the most competitive against weeds while erect cultivars are the least (Yirefu et al., 2012).

In this study, the interference of Brachiaria brizantha on sugarcane cultivars yield was evaluated, in order to assess the economic threshold levels for populations of $B$. brizantha in competition with the sugarcane cultivars RB72454, RB867515 and SP801816.

\section{MATERIAL AND METHODS}

The experiment was conducted in a Red-Yellow Argisol. Sugarcane was planted in 2008 , in a conventional tillage system, with plowing followed by disking, with a posterior furrow of soil between $1.4 \mathrm{~m}$ rows.

Fertilization was performed in the furrow of planting, according to the results of soil analysis and following recommendations for the crop, using $500 \mathrm{~kg} \mathrm{ha}^{-1}$ of $8-28-16 \mathrm{NPK}$ as formulation, with $160 \mathrm{~kg} \mathrm{ha}^{-1} \mathrm{KCl}$ in topdressing. Planting density was 18 buds per 
meter, and the seedlings were sectioned in cuttings of two or three buds each. Planting was carried out in November, using the oneyear old sugarcane system.

The experimental units were composed of six lines $(8.4 \mathrm{~m})$ with $5.0 \mathrm{~m}$ in length, making the total area of $42 \mathrm{~m}^{2}$ and useful area of $22.4 \mathrm{~m}^{2}$. The treatments consisted of populations of $B$. brizantha and three sugarcane cultivars. The average densities of $B$. brizantha were $0,1,3,7,15,32,32,40,64$ and $72 ; 0,1,4,10,14,18,28,30,36,52,54$ and 72 , and $0,1,3,6,14,20,24,26,32,46$ and 56 plants per $\mathrm{m}^{2}$ for cultivars RB72454, RB867515 and SP801816, respectively. The cultivars were chosen because they are widely grown and have different leaf architecture.

Populations of $B$. brizantha were obtained by seeding, carried out ten days before sugarcane emergence, at a density proportional to the populations of desirable plants, with a safety margin. When the plants were at the stage of two leaves per grass tiller, the population was considered established. For that purpose, the desired populations of $B$. brizantha were protected with plastic cups in order to avoid damage from the herbicide MSMA (2.0 $\mathrm{L} \mathrm{ha}^{-1}$; Volcane ${ }^{\mathbb{R}}$ ) which was then applied, while taking care to avoid spraying the youngest leaves of sugarcane directly so as to not cause intoxication. The herbicide was applied using a $\mathrm{CO}_{2}$ backpack sprayer, fitted to a $2 \mathrm{~m}$ long bar containing four spray tips, spaced $0.5 \mathrm{~m}$ apart (model TT110.02), calibrated to apply $150 \mathrm{~L} \mathrm{ha}^{-1}$ of spray volume.

The evaluation of plant populations (PP) of B. brizantha was performed 60 days after emergence. The population of plants (PP) was determined by counting the plants contained in two areas of $0.25 \mathrm{~m}^{2}$ randomly chosen in each experimental unit. Weed species that were not the target of this study were controlled with herbicide 2,4-D (broadleaf) and weeding (narrow leaf).

Quantification of stalk yield was performed 12 months after planting the crop, by counting the stalks present in the four central lines and disregarding $0.5 \mathrm{~m}$ at the beginning and end of each plot. Later, 30 stalks from each plot were cut at random, and then weighed. Based on the average weight of stalks and the number of stalks per area, yield was estimated by extrapolating the values for ton $\mathrm{ha}^{-1}$. Yield data were transformed into a percentage relative to the control plot, which was free of weeds.

The relationship between the percentage losses of sugarcane stalk yield, according to the PP, were calculated for each cultivar, using the non-linear regression model derived from a rectangular hyperbola, proposed by Cousens (1985) (Equation 1).

$$
P L=\frac{(i * X)}{\left(1+\left(\frac{i}{a}\right) * X\right)}
$$

where PL = yield loss (\%) $X=$ population of plants (PP) $B$. brizantha, $i=$ yield losses $(\%)$ per unit of plant $B$. brizantha when the value of the population approaches zero, and $a=$ maximum yield loss (\%) with the increase of population of $B$. brizantha.

Data adjustment to the model was carried out by the non-linear regression procedure "Proc Nlin" using the statistical program SAS ${ }^{\circledR}$ (SAS Institute, Cary, NC). The Gauss-Newton method was used for this calculation. By successive iterations, it estimates parameter values in which the sum of squared deviations of observations regarding the adjusted model is minimal. The value of the F statistic $(\mathrm{p} \leq 0.05)$ and the coefficient of determination $\left(\mathrm{R}^{2}\right)$ were used as criteria for data adjustment to the model.

To calculate the economic threshold level (ETL), the estimates of the parameter $i$ obtained from equation 1 and the equation adapted from Lindquist and Kropff (1996) (Equation 2) were used:

$$
E T L=\frac{(C c)}{\left[R * P *\left(\frac{i}{100}\right) *\left(\frac{H}{100}\right)\right]}
$$

where $E T L=$ economic threshold level (plants per $\mathrm{m}^{2}$ ), $C c=$ cost of control (herbicide and application by tractor, in dollars ha-1); $R=$ sugarcane stalks yield (ton ha ${ }^{-1}$ ), $P=$ price of sugarcane stalks (dollars ton ${ }^{-1}$ of stalks); $i=$ yield losses $(\%)$ per unit of plant $B$. brizantha when the value of the variable approaches zero, and $H=$ herbicide efficiency level (\%). 
Three values were used for the variables $C C, R, P$ and $H$ (Equation 2). Thus, for the cost of control $(C c)$, the average price of $\$ 95.00 \mathrm{ha}^{-1}$ (3.0 kg ha-1 of herbicide Velpar K WG ${ }^{\circledR}$ (diuron + hexazinone) was considered in addition to the cost of application by tractor; the minimum and maximum costs increased or decreased by $25 \%$ compared to the average cost $(\$ 72.00$ and $\$ 108.00$, respectively). Sugarcane stalk yield $(R)$ was considered as the average yield of 95 ton ha ${ }^{-1}$ (productivity of the first cut) and $20 \%$ variation for lower and higher yield (76 and 114 ton ha-1 stalks, respectively). The price paid for sugarcane stalks $(P)$ was estimated from the value obtained at the end of the 2009 crop of $\$ 27.00$ ton $^{-1}$, considering a range of $20 \%$ for lower and higher prices $(\$ 20.00$ and $\$ 34.00 \mathrm{t}^{-1}$ stalks, respectively). The values for herbicide efficiency $(H)$ were established on the order of 80,90 and $100 \%$ of control; a minimum of $80 \%$ weeds control is considered effective.

In simulations of ETL, the intermediate values were used for those variables that were not the object of calculation.

\section{RESULTS AND DISCUSSION}

The explanatory variable plant population (PP) presented an appropriate adjustment to the rectangular hyperbolic model, and was suitable for estimating sugarcane stalk yield loss. This variable presents some advantages over others because it can be quantified easily, quickly and with low costs (Table 1).

In the estimation of yield, the parameter $i$ of the estimation model for the yield loss of cultivar RB867515 presented a value greater than the other cultivars, thus showing the greater interference of low populations of $B$. brizantha for this cultivar (Table 1). This parameter is used as an index to compare the relative competitiveness among cultivars (Galon and Agostinetto, 2009), in which higher values represent cultivars that have a lower competitive ability or that present higher yield loss with an increase by one unit of B. brizantha.

Cultivar SP801816 presented lower values of $i$, which indicates a higher competitive ability compared with other cultivars, because it has high vigor and high tillering capacity. Cultivar RB72454 presented intermediate values. The difference in the competitive ability of cultivars of a cultivated species is a common characteristic, as observed for rice cultivars (Galon and Agostinetto, 2009). The faster the crop growth and the soil coverage, the higher is the competitive ability with weeds (Westendorff et al., 2014).

Parameter $a$ of the rectangular hyperbolic model represents yield loss when the population of weeds is maximum, which determines the largest losses. This parameter allows the comparison of the maximum yield losses among cultivars of a particular crop (Westendorff et al., 2014; Machado et al., 2015). This parameter was lower (76.17) for cultivar SP801816, showing, once again, the least yield loss of this cultivar when in competition with $B$. brizantha; other cultivars presented similar values for this parameter (Table 1).

The difference in competitive ability among cultivars may be related to their intrinsic characteristics. The low competitive ability of cultivar RB867515 with $B$. brizantha may be relative to the slower initial sprouting and lower tillering capacity compared with

Table 1 - Parameters of rectangular hyperbolic model of sugarcane stalk yield loss, based on cultivars and populations of Brachiaria brizantha

\begin{tabular}{|l|c|c|c|c|}
\hline \multirow{2}{*}{ Cultivar } & \multicolumn{2}{|c|}{ Parameter } & \multirow{2}{*}{ QMR $^{2 / *}$} & \multirow{2}{*}{$\mathrm{R}^{2}$} \\
\cline { 2 - 5 } & $i^{\frac{1}{\prime}}$ & $a^{\underline{1}^{\prime}}$ & 90.20 & 0.95 \\
\hline RB72454 & $8.48( \pm 2.49)$ & $87.70( \pm 7.12)$ & 43.22 & 0.98 \\
\hline RB867515 & $11.80( \pm 2.51)$ & $76.17( \pm 14.73)$ & 98.82 & 0.97 \\
\hline SP801816 & $5.91( \pm 2.36)$ & & \\
\hline
\end{tabular}

${ }_{1}^{1 /}$ Value obtained by the rectangular hyperbolic model (Cousens, 1985), followed by the standard error, ${ }^{2} /$ residual mean square, $*$ Significant $(\mathrm{p}<0.05)$. 
SP801816. According to Paolini et al. (1998), crops that have low ground cover allow greater light penetration through the canopy of the community and are therefore less competitive with weeds. More vigorous plants are established earlier in these areas, and they obtain a competitive advantage over those that are established later (Trezzi et al., 2014). According to Yirefu et al. (2012), sprawling sugarcane cultivars appear to be the most competitive with weeds while erect cultivars are the least.

Based on parameter $i$, cultivar RB867515 was the most negatively affected by an increase in the population of the competitor, with losses of 11.8 ton ha her $^{-1}$ perit of $B$. brizantha by $\mathrm{m}^{2}$ with the smallest populations of this weed. On the other hand, cultivar SP801816 showed the lowest yield loss, with a loss of 5.91 ton ha-1 per unit of $B$. brizantha per $\mathrm{m}^{2}$ (Table 1). Sugarcane cultivars, due to their intrinsic characteristics, may respond differently to weed competition (Yirefu et al., 2012). The increase in $B$. brizantha density promotes lower values for leaf area and stalk number of sugarcane (Galon et al., 2011), resulting in yield loss.

The estimates for ETL for populations of $B$. brizantha varied among cultivars (Figure 1 and 2). In general, the cultivar most influenced by populations of $B$. brizantha was RB867515, in which ETL was reached with the smallest population. Therefore, it is economical to perform control practices when

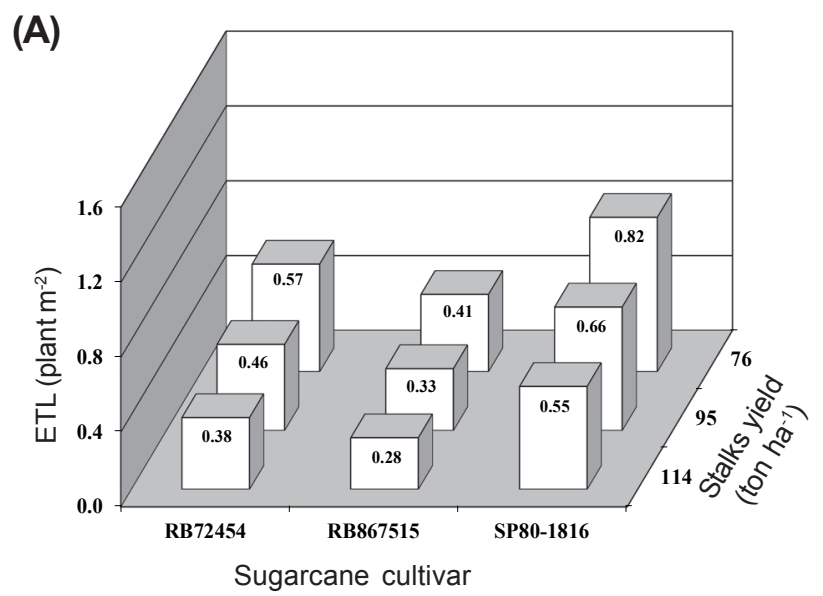

0.33 plants of $B$. brizantha are present per $\mathrm{m}^{2}$, considering the intermediate yield values, cost of control, stalks price and control efficiency. Under these conditions, ETL was achieved with 0.46 and 0.66 plants $\mathrm{m}^{-2}$ for cultivars RB72454 and SP801816, respectively.

These results highlight the considerable interference of this species in sugarcane cultivar growth. The low values of ETL are attributed to the low competitive ability of the crop, which is planted with wide spacing between lines. Thus, the crop canopy delays covering of the soil surface, allowing light to penetrate and supporting the development of plants such as $B$. brizantha, which presents rapid growth and high tillering capacity.

The plants of Brachiaria species have rapid growth and high competitive capacity, as observed for $B$. decumbens, which promoted a yield loss of 1 ton ha-1 of sugarcane stalks for every $3.70 \mathrm{~g} \mathrm{~m}^{-2}$ of accumulated dry matter (Kuva et al., 2003).

With an expected increase in yield, there was a significant reduction in the population of $B$. brizantha, enough to reach ETL. In order to increase yield from 76 to 114 ton $\mathrm{ha}^{-1}$, the ETL was reduced from 0.41 to 0.28 , from 0.57 to 0.38 and 0.82 to 0.55 plants of $B$. brizantha per $\mathrm{m}^{2}$ for cultivars RB867515, RB72454 and SP801816, respectively (Figure 1A). With an increase in expected yield, the crop should be less influenced by environmental factors such

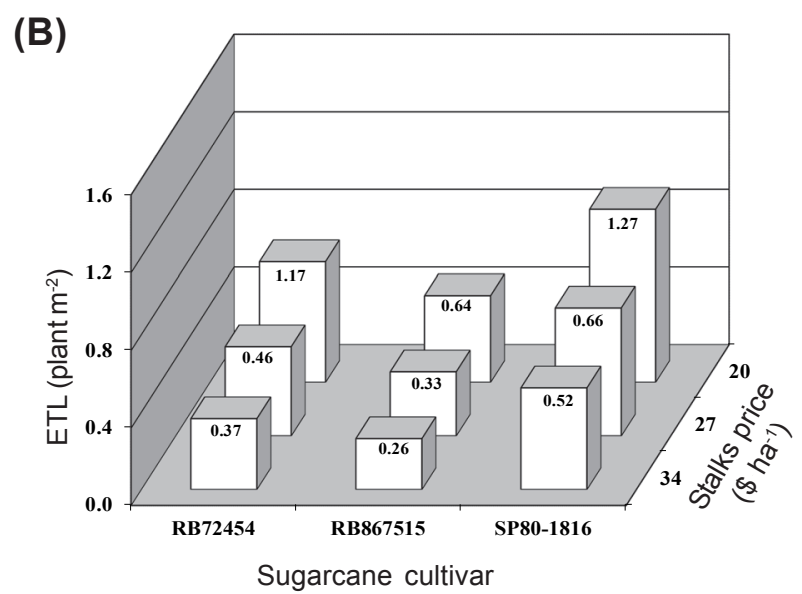

Figure 1 - Economic threshold level (ETL) of Brachiaria brizantha populations for sugarcane plants, according to yield (A) and stalk price (B) in sugarcane cultivars. 

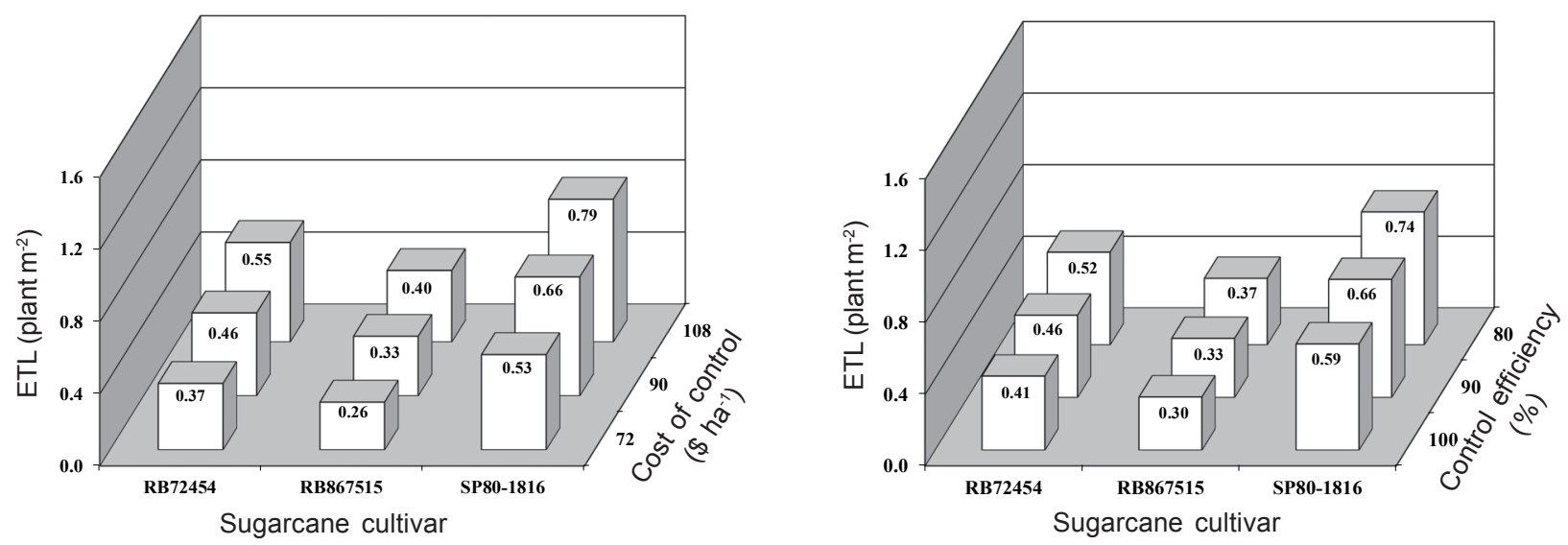

Figure 2 - Economic threshold level (ETL) of Brachiaria brizantha populations for sugarcane plants, according to cost (A) and control efficiency (B) in sugarcane cultivars.

as competition with weeds (Westendorff et al., 2014; Machado et al., 2015). The low ETL found for sugarcane cultivation is due to the high yield of the crop, in which a yield loss of less than $4 \%$ (considering intermediate values) inflicts economic damage that justifies weed control.

A similar result was found by Galon and Agostinetto (2009) when studying the ETL of barnyard grass on flooded rice. This study concluded that, even when barnyard grass was found at low densities (less than one plant per $\mathrm{m}^{2}$ ), there was a need to adopt some measure of control due to the high competitiveness of this weed species with the flooded rice.

The price paid for the stalks also influences ETL, because the greater the value of the product, the lower the weed population sufficient to achieve ETL. With a reduction in the price paid for stalks to $\$ 14.00$ ton $^{-1}$, the population of $B$. brizantha required to reach ELT increased from 0.26 to 0.64 plants per $\mathrm{m}^{2}$ for cultivar RB867515 and 0.52 to 1.27 plants per $\mathrm{m}^{2}$ for cultivar SP801816 (Figure 1B). These results show the great variation in ETL with changes in the value of the harvested product. When the highest amount by the stalk is paid, yield losses represent greater economic importance, justifying weed control because they interfere in yield even to a small degree. The similar result was observed by Safdar et al. (2015), when they studied corn in competition with parthenium weed (Parthenium hysterophorus), that is, an increase in weed density decreases corn grain yield. The ETL of parthenium weed was 1.2 and 1.0 plants $\mathrm{m}^{-2}$ during year 2012 and 2013, indicating that weed should be controlled even at a low density.

Another variable of great importance for the estimation of ETL is the cost of control of the weeds that compete with crops. If the cost of the damage caused by weeds is equal to or greater than the cost of control, ETL is reached (Trezzi et al., 2014).

A higher cost of control of $B$. brizantha resulted in the need to increase the population of this species in order to reach ETL. When the cost of control increased from $\$ 72.00$ to $\$ 108.00$ (an increase of $\$ 36.00$ ), there was the need for an increase by $50 \%$ in the population of $B$. brizantha to reach ETL (Figure 2A).

The efficiency of the method of weed control also changes ETL because if a method in use has lower efficiency, ETL will be achieved with a larger population of weed species (Galon and Agostinetto, 2009). As the simulation of herbicide use showed a control efficiency of 80,90 or $100 \%$, changes in the population of $B$. brizantha were necessary to achieve ETL.

Considering the average values of the other variables, with a variation in the average control efficiency $(90 \%)$ compared to the lowest $(80 \%)$ or greatest $(100 \%)$ efficiency, changes of approximately $25 \%$ in the population of $B$. brizantha were required to reach ETL, for 
all sugarcane cultivars tested. With higher efficiency of control, ETL is achieved with a smaller population of competing plants (Figure 2B).

Economic threshold level values could be even lower if the variable of seed production was included, because a small population of weeds can produce a large amount of seeds that could emerge and compromise the crops yield in subsequent years. Thus, if that variable were considered, ETL would be reached with even smaller populations of $B$. brizantha (Parsons et al., 2009). Studies proposing an optimal economic threshold level should also consider seed production as a variable (Dodamani and Das, 2013).

Weed ETL can be evaluated in a mixedspecies population and in a real life farm situation. The comparison among experiments can be more reliable when using simulations of the weed ETL with different crop grain prices and weed control costs. In general, the weed economic threshold is reduced with the increment of the crop grain prices and with the reduction of weed management costs (Vidal et al., 2010).

An increase in sugarcane yield potential, in the price paid per ton of stalks or in herbicide efficiency, as well as lower costs of control, reduced ETL for the three sugarcane cultivars. Thus, in sugarcane fields in which the yield estimates are high, weeds should be managed more efficiently, because the higher yield, the higher potential limitation of yield by weeds. In this case, ETL is reached with smaller populations of weeds.

The results of this study confirm that ETL for $B$. brizantha varies according to sugarcane cultivars. Considering the average values, ETL was reached with a population of $0.33,0.46$ and 0.66 plants of $B$. brizantha per $\mathrm{m}^{2}$ for cultivars RB867515, RB72454 and SP801816, respectively. Higher yield, higher price paid by the stalk, higher herbicide efficiency and lower costs of control decrease the population of $B$. brizantha required to achieve ETL.

\section{ACKNOWLEDGEMENTS}

We would like to thank the Scientific and Technological Development National Council
(CNPq) for providing financial support and scholarships.

\section{REFERENCES}

Ali A. et al. Image-based thresholds for weeds in maize fields. Weed Res. 2014;55:26-33.

Barbosa E.A. et al. Dinâmica de infestação de plantas daninhas em variedades de cana-de-açúcar. Biosci J. 2013;29:1920-31.

Cousens R. An empirical model relating crop yield to weed and crop density and a statistical comparison with other models. J Agric Sci. 1985;105:513-21.

Dodamani B.M., Das T.K. Density and nitrogen effects on interference and economic threshold of common lambsquarters in wheat. J Pestic Sci. 2013;86:611-9.

Faria A.T. et al. Efeitos de herbicidas na atividade da microbiota rizosférica e no crescimento da cana-de-açúcar. Biosci J. 2014;30:1024-32.

Galon L. et al. Interferência da Brachiaria brizantha nas características morfológicas da cana-de-açúcar. Planta Daninha. 2011;29:1029-36.

Galon L., Agostinetto D. Comparison of empirical models for predicting yield loss of irrigated rice (Oryza sativa) mixed with Echinochloa spp. Crop Prot. 2009;28:825-30.

Kuva M.A. et al. Períodos de interferência das plantas daninhas na cultura da cana-de-açúcar. III - capim-brachiaria (Brachiaria decumbens) e capim-colonião (Panicum maximum). Planta Daninha. 2003;21:37-44.

Lindquist J.L., Kropff M.J. Application of an ecophysiological model for irrigated rice (Oryza sativa) Echinochloa competition. Weed Sci. 1996;44:52-6.

Machado A.B. et al. Rendimento de grãos de feijão e nível de dano econômico sob dois períodos de competição com Euphorbia heterophylla. Planta Daninha. 2015;33:41-8.

Odero D.C. et al. Response of energycane to pre-emergence and post-emergence herbicides. Weed Technol. 2015:29:81020 .

Paolini R. et al. Competition between safflower and weeds as influenced by crop genotype and sowing time. Weed Res. 1998;38:247-55.

Parsons D.J. et al. Weed manager-A model-based decision support system for weed management in arable crops. Comp Electron Agr. 2009;65:155-67.

Planta Daninha, Viçosa-MG, v. 34, n. 4, p. 649-656, 2016 
Queiroz S.N.C. et al. Comportamento do herbicida hexazinone em área de recarga do aqüífero Guarani cultivada com cana-de-açúcar. Quím Nova. 2009;32:378-81.

Safdar M.E. et al. Yield losses in maize (Zea mays) infested with parthenium weed (Parthenium hysterophorus L.). Crop Prot. 2015;70:77-82

Tironi S.P. et al. Efficiency of a reduced herbicide rate for Brachiaria brizantha control in sugarcane. Planta Daninha. 2012;30:791-8

Trezzi M.M. et al. Impact of Conyza bonariensis density and establishment period on soybean grain yield, yield components and economic threshold. Weed Res. 2014;55:3441
Vidal R.A., Kalsing A., Gherekhloo J. Interferência e nível de dano econômico de Brachiaria plantaginea e Ipomoea nil na cultura do feijão comum. Ci Rural. 2010;40:1675-81.

Warner B.D. et al. Developing an empirical yield-prediction model based on wheat and wild oat (Avena fatua) density, nitrogen and herbicide rate, and growing-season precipitation. Weed Sci. 2007;55:652-64.

Westendorff N.R. et al. Yield loss and economic thresholds of yellow nutsedge in irrigated rice as a function of the onset of flood irrigation. Bragantia. 2014;73:32-8.

Yirefu F. et al. Competitive ability of sugarcane (Saccharum officinarum L.) cultivars to weed interference in sugarcane plantations of Ethiopia. Crop Prot. 2012;32:138-43. 